\title{
Development of English Teaching Materials Based on Language Meta-Function in UNIMED Postgraduate
}

\author{
Busmin Gurning \\ Department of English Language and Literature \\ State Universityof Medan (UNIMED) \\ Medan-North Sumatra, Indonesia \\ busmingurning@gmail.com
}

\author{
Sri Minda Murni \\ Department of English Language and Literature \\ State University of Medan (UNIMED) \\ Medan-North Sumatra, Indonesia \\ mindasri@yahoo.co.id
}

\begin{abstract}
This study aims to find useful teaching materials to be in accordance with the principles of language function and ESP to develop English language skills for academic and work world purposes. This research was conducted in the UNIMED Postgraduate study program in 2017 until 2018. To achieve the objectives of this research, the overall research used research and development methods. The implementation of this study follows the steps including: preliminary survey, model planning, model testing, model development and socialization validation. To find out the influence of relevant learning models that can improve good English competence and are supported by the ability to think critically in student language used a quasiexperimental research approach with the design of posttest only control groups. This study uses an instrument consisting of questionnaires and tests. Data were analyzed using descriptive analysis techniques and $t$ test. The results of the study show that language metaphysics relate to the development of English as a foreign language for Postgraduate study programs. The development of teaching materials is closely related to the analysis of needs in metaphors and critical thinking and genres. Metaphysical material is closely related to the principle of language learning related to how to develop teaching materials that are relevant to students' problems.
\end{abstract}

Keywords--English teaching materials, Language Metaphysics

\section{INTRODUCTION}

The English language curriculum has undergone changes in various levels of education as an anticipative effort to fulfill reliable English language skills.Postgraduate schools are not spared on this issue. Doctoral study program designs curriculum that emphasizes the role of study programs in interdisciplinary linguistic studies, for example between linguistics and other fields, including in linguistics studies in neurology, linguistics in forensics, linguistics in the genre. The postgraduate school prepares graduates to become experts and able to encourage their students in their fields in the wider 'employment field'. Skilled personnel in this field increases again with better mastery of English language both oral and written which can support higher professionalism.

The curriculum change has changed not only in the LTBI study program, but also in English courses in various study programs of postgraduate. The curriculum change is a representation of improving the quality of learning. Improving the quality of English learning is directed at mastering English for the purpose of communication both oral and written. School graduate from postgraduate in State University of Medan which consists of 15 master study programs that have their own characteristics that cannot be ignored by not making improvements in the process or provision of teaching materials. Increasing the role of oral language or written language is equivalent to that of postgraduate education; can communicate science at various national or international seminar opportunities. The role of English in this case is not neglected. However, it is apparent that the capabilities possessed are not in line with the acquisition of the degree they have. An alumni should have good English language skills in both writing and speaking skills.

Many factors cause less ability of such students, such as selection tests that do not consider the quality of inputs. As a result all prospective students are accepted without screening with certain test standards. Another factor is the provision of inadequate teaching materials that can encourage student learning motivation. The teaching material used is still about grammar-oriented and reading comprehension, although sometimes the teaching material has been mixed with the material of the journal source.Presentation of such teaching materials also does not encourage students to study well. As a result the achievement of learning English in both oral and written languages is still weak.

The learning process is strongly related to the material used not in accordance with the learning needs of students.Presentation of teaching materials that have not been able to encourage students to have English language skills to be able to write or read well as needed for performance and for other social purposes[1].Postgraduate school strives to provide teaching materials by making relevant designs in accordance with academic needs.

The acceleration of the acquisition of English at postgraduate school needs attention. English has not been used in full subject learning. In the learning process, lecturers still apply Reading and Writing teaching materials by introducing limited text forms such as descriptive, narrative, argumentative, not genre-based (genre-based instruction) (recount, procedure, narrative, etc.). 
In developing more meaningful English language skills, it is necessary to pay attention to the role of critical thinking in the learning process. This is done by the teacher without being modest. English learning has not integrated the learning process with critical thinking skills which will be more meaningful if the learning process is carried out in a togetherness. Empowerment of students' potential in learning is applied to cooperative learning for example by orienting the learning community. According to Slavin (1991) with cooperative learning, students learn together to complete the material and share ideas. Critical thinking is a mental process of analyzing or evaluating information. Information can be obtained from observations and experiences. Through critical thinking students can activate their ability to analyze and evaluate evidence, identify questions, and logical conclusions [2].

However, these efforts for the community have not been satisfactory, still visible in plain sight by members of the postgraduate quality graduate school in community. This has an impact on business confidence in the acceptance of postgraduate school's graduates. As a result the value of the bargaining position of graduates is still low; alumni are paid low salaries. In line with this lack of trust, Gurning (2012) published as many as 9.427 .600 people, the number of unemployed people in Indonesia which included the category of open unemployment until February 2008; there are 4.516.100 consisting of high school, vocational school, diploma and university graduates. This reality can indicate that more comprehensive efforts are needed to make graduate schools as institutions that can improve the quality of graduates, so that vocational school graduates can master competencies that are in accordance with areas of expertise that are relevant to the field of education in general and the business field or the industrial field[3].

Based on the description above, it has become a recent fairness that graduates of the postgraduate School can understand realistically the current state of progress in relation to the problem of increasing individual competence.Improving English language competence is one of the goals of education at the Postgraduate school that organizes education in eleven study programs.

\section{A. Meta-function-based English Development as ESP Realization}

Meta-function-based English learning means learning English in accordance with language functions. This is important because students learn English in the context of their language. besides, this will facilitate the improvement of communication skills, critical thinking and the ability to interact with professionals and academics.

The English element is to express different metafunction-based content. This category is very clear in the natural sciences and social sciences disciplines. The difference is due to scientific characteristics themselves. The text of natural sciences such as Physics is different from the text of the Chemistry discipline, although it is dominated by equations. Another thing, the text of the natural sciences is different from the texts of the social sciences [4]. Based on this difference, it is necessary to develop teaching materials based on different natural sciences with social science disciplines. The same thing will happen in several postgraduate study programs, such as Educational Technology, Educational Administration, Economics, Mathematics Education, and Sports Education. English learning is oriented to disciplines. Students can learn the contents of the scientific discipline through the language carrier. The application of the ESP concept also adds more macro insight in understanding discipline as a science, packed in better learning. How great is the difference that affects the development of teaching materials and the learning process.

The development of English learning is carried out with the principle of English for a specific purpose (ESP). ESP consists of two types, one of which is English for the purpose of the world of work which is commonly called occupational (EOP) [5]. ESP is an approach to teaching English as a foreign language or second language, which aims to empower students with special needs, not least for academic or personal purposes. This ESP concept was developed based on functional linguistics [6]. Functional linguistics emphasizes its mission of language acquisition based on language usage, language function in a social context, and also word patterns that produce meaning [7].

Halliday (2004) proposes functional concepts in linguistics with three interrelated things. First, systemic functional linguistics describes how language is used in semiotic language systems [6]. This language exposure based on linguistics includes how language functions in human life. Language is formed to meet human needs. The use of language is what forms the language system. Language is not arbitrary but natural because all aspects can be explained in the explanation of how language is used.

Second, with regard to the first view, the fundamental element determining the meaning of language is the function of language. All languages are formed or structured to convey three meanings known as meta-function in the linguistic system, namely (1) understanding experience or environment (ideational meaning), (2) exchanging experiences (interpersonal meaning), and (3) integrating experiences (textual meaning).

Third, each element in language is explained by referring to the overall linguistic system. All language units such as clauses, phrases, groups and phonemes are organic configuration functions. In other words, each element of language can be explained functionally in relation to the larger system and finally to the overall language system.

Added again that EOP can be grouped into business English, English for professional (English for doctors or advocates) and vocational English (English for tourism, aviation and nursing). This EOP emphasis is on engineering or business communication skills. Students are expected to have the skills to communicate various things related to their fields and the goals of the work field. Therefore EOP emphasis is on the function of language, mood, speech function, non-speech, language politeness, and grammatical metaphor. All elements of language included in English for occupational purposes are 
packaged in different forms to realize that language is a choice.

Text is a language unit or semantic unit and not a grammatical unit. Language can function that is in the context or social functional in a social context (Halliday, 2004). In line with this, Gurning (2006) has found differences in English text in Physics and History in lexycogrammatics (physics texts are built based on higher grammatical intricacy, Historical texts are built based on phrases filled with phrases, as a result the text has a large more than the Physics text, this example gives us confidence that each text has different characteristics and is realized in different forms of language [8].

Gurning (2005) concludes in his research that the development of information in academic texts tends to be more dynamic because it is realized with linear progression, whereas literary texts tend to be more repetitive realized with constant progression [4]. The results of the study indicated the difference in functional development of information as a result of the realization of different text contexts and genres.

Anticipative and adaptive efforts towards the development of science and technology, education and teaching science continues to grow rapidly. One form of the development of education and teaching science is the emergence of innovative ideas which basically aim at improving the quality of education and teaching itself including learning English both macro and micro.

\section{B. Context and Language Meta-function}

Language function is a function of language in language usage by speakers of language. Every interaction between language users and language speakers uses language to expose or realize experience, exchange experiences, and organize or organize experiences in written language. In realizing this experience, language users involve the process by linking it to participants and circumference. The three functions of the language, the language at the same time are called three functions, namely ideational functions (experiential and logical), interpersonal functions, and textual functions [6].

TABLE 1. Context And Meta-Function Relations

\begin{tabular}{|l|l|l|}
\hline \multicolumn{1}{|c|}{$\begin{array}{c}\text { Situation: Context } \\
\text { Feature }\end{array}$} & (Realized by) & Meta-function: Realization \\
\hline $\begin{array}{lll}\text { Topic (Field) } \\
\text { (What happened) }\end{array}$ & $\begin{array}{l}\text { Experimental function } \\
\text { (transitivity, clause, ...) }\end{array}$ \\
\cline { 1 - 1 } $\begin{array}{l}\text { Actor (Tenor) } \\
\text { (who took part) }\end{array}$ & $\begin{array}{l}\text { Interpersonal function } \\
\text { (mood, modality ...) }\end{array}$ \\
\cline { 1 - 1 } $\begin{array}{l}\text { Mode (role section with } \\
\text { language) }\end{array}$ & $\begin{array}{l}\text { Textual function(themes, } \\
\text { information, cohesion) }\end{array}$ \\
\hline
\end{tabular}

\section{Mindset in Language Learning}

Jordan (2007) state that critical thinking skills are highlevel thinking activities [9]. Critical thinking activates the ability to conduct analysis and evaluation of evidence, identify questions, logical conclusions, understand the implications of the argument [10].McMurrary et al (1991) states that critical thinking is a very important activity to be developed in schools, teachers are expected to be able to realize learning that activates and develops the ability to think critically in students[11].In another case, Ordonez (1996) said that learning by increasing critical thinking skills would be more meaningful if in the process, learning was carried out in a togetherness[12]. Empowerment of students' potential in learning is applied to cooperative learning oriented to learning communities, Building and applying information and knowledge logically, critically, creatively, and innovatively, Demonstrating the ability to think logically, critically, creatively, and innovatively in decision making is a skill that must be owned by students.

Learning activities in English subjects should provide opportunities for intellectual capital development. But the reality that happened in Indonesia, especially at the secondary school level the teacher did not pay attention to aspects of thinking skills in the learning process [13].In reality, simply critical thinking can be learned through practice, like playing tennis or swimming. The teacher must prepare a plan to realize critical thinking by organizing learning goals and paying attention to values or perceptions, assumptions, concerns, and assessments that are closely related to thinking skills. The teacher can activate critical thinking in the classroom through students' concern for understanding and the surrounding environment. Through the interaction between the learning approach and the teaching material of concern, perceptions, assumptions, values and presuppositions of old values can be transferred to new views[14]

The application of critical thinking in language learning can be done by first directing to begin and guide critical thinking. In the language class there are two important things that must be done by the teacher, namely preparing rich teaching materials and applying interactive approaches. In the development of critical thinking, self-care becomes very important, because students can understand the relationship between mind and emotion as discussed earlier. Another thing that can be done by the teacher is to keep students concerned about perceptions, assumptions, prejudices, and values. In research conducted by Dietz-Uhler\&Lanter (2009) quoted from Alexander et al (2010) concluded that the development of critical thinking in education can improve critical thinking. His previous research also shown that learning strategies that promote active learning can also develop students' ability to think critically about knowledge, action, and beliefs [15] Critical thinking has been assessed as a tool for giving learning and learning by emphasizing the need for consistency, application, synthesis, and evaluation of information through observation, experience, reflection, reasoning and communication. Through the technique of four questions, such as analyzing, reflecting, relating, and questioning, offering learning techniques that can effectively improve critical thinking.

The main goal of developing critical thinking in learning is to change the teaching (teaching) paradigm shifting to the learning paradigm, from behavioristic understanding to constructivist understanding, from teacher centered toward student-centered learning. Another goal of critical thinking in learning is to enable and empower students to learn actively, creatively, and innovatively as the realization of student- 
centered learning[16]. The learning process that refers and is relevant to this is cooperative learning. Cooperative learning can be used to improve creative thinking skills, attitudes, evaluation, social skills, and practical skills of students. According to Slavin (1991) with cooperative learning students do joint learning to complete the material and share ideas. $\mathrm{He}$ further stated that cooperative learning will train students in diversity and social skills. Thus critical thinking is thought to be used to help the learning process that is more efficient in learning English[2].

\section{METHODOLOGY}

To achieve the overall objective of this study, this research uses research and development (R \& D) method[17]. Based on the research and development approach, the implementation of this study follows the steps: preliminary survey, planning of teaching material development models, and socialization.Meanwhile, to find out the effect of teaching materials developed, a quasi-experimental research approach was conducted with the design of posttest control group only. The research was carried out in the State University of Medanin Postgraduate School study program. The research was conducted for 3 years, from 2018 to 2020, as illustrated in the research paradigm above.

The object of this study is in 11 departments of postgraduate which organize English.The research instruments which are used include questionnaires, recording documents and tests. There are several data analysis techniques which is used, including analysis of needs at the initial stage, descriptive analysis of research data through surveys. Content analysis will be conducted to find competencies and materials that are appropriate to the level of postgraduate education in order to provide students with English language skills that are relevant to the needs of scientific disciplines. In quantitative data analysis in quasiexperimental research, technical analysis of $t$ test and analysis of variance were used.

\section{RESULTS OF RESEARCH}

\section{A. Test Preparation for Teaching Materials}

Preparation of teaching materials was conducted to find the form and scope of teaching materials provided in the Postgraduate School study program at the State University of Medan which can improve students' English competence in accordance with academic goals.

Preparation of teaching materials is conducted to find the form and scope of the development of meta-function based teaching materials and teaching materials that are in line with learning that encourages students to think critically in accordance with the competence of the academic field.

The assessment was carried out by two teaching materials experts through instruments compiled and used in the development of teaching materials. Some aspects reviewed by experts were compiled in the form of basic questions on the analysis of the development plan for English language teaching materials based on meta-function.

The following is an explanation of the results of the trial of the learning process using the teaching materials that have been developed. The following will show the results of the tests that are assessed by instructors, including the feasibility of planning, implementation and evaluation.

Basically the teaching material presented has teaching materials that are relevant to the lectures or English courses at the State University of Medan in Postgraduate School study program. The relevance of this teaching material with the subject becomes the main characteristic and becomes the excellence of this research. Language-based teaching materials are relevant to the field of Education Administration studies based on the Education Administration syllabus. All teaching materials provided in accordance with the field of study and development are aligned with the study program.

Teaching materials are designed to meet the special needs of postgraduate program students in Education Administration. Teaching materials require more adequate methodology and activities for postgraduate students. Teaching materials encourage students to master grammar, vocabulary, registers, discourses, genres that are appropriate in accordance with activities.

The development and preparation of teaching materials is based on the availability of materials according to curriculum requirements, target characteristics, and learning problem solving demands. In addition, the development of teaching materials must pay attention to the demands of the curriculum, it means that the learning material to be developed must be in accordance with the curriculum. In the Curriculum Based on competency, the Graduates Competency Standards have been established by the government, but how the strategies for achieving them and what teaching materials to use are the full authority of the lecturers as professionals.

\section{B. Benefits and Role in Preparing Teaching Materials}

Benefits and roles in the preparation of instructional materials are based on the first, obtained teaching materials that match the curriculum's requirements and in accordance with the learning needs of students; second, it is no longer dependent on textbooks that are sometimes difficult to obtain, thirdly, teaching materials become richer because they are developed using various references, fourth, adding to the repertoire of lecturers' knowledge and experience in writing teaching materials, fifth, teaching materials will be able to build effective learning communication between lecturers and students.

Broadly speaking, the steps for selecting teaching materials include: (a) identifying aspects contained in the basic competency and competency standards that are the reference in selecting teaching materials, (b) identifying the types of teaching materials, (c) selecting materials teaching that is appropriate or relevant to the competency standards and basic competencies that have been identified earlier, and (d) choosing the source of teaching materials. In full, the steps for selecting teaching materials can be explained as follows.

Analysis of the needs of students in postgraduate programs is different from teaching materials given in undergraduate or secondary school programs. University students' needs for English language teaching materials are different from the teaching materials needed by other study programs. At the postgraduate level, they demand that they use higher teaching materials and are more relevant to their studies. 
Identifying aspects of standard competencies and basic competencies that students must learn or master must be in line with various types of aspects of competency standards, learning materials can also be divided into types of cognitive, affective, and psychomotor aspects. Cognitive aspects of learning material in detail can be divided into four types, namely: facts, concepts, principles and procedures [18].

\section{Validation of Teaching Materials}

Validation of teaching materials is needed to determine whether the teaching material is appropriate or not.The suitability of this teaching material is determined by the adequacy of the teaching material itself by considering matters relating to several criteria of teaching materials. After this validation is carried out, the assessment is also carried out through instruments that can show the device directly or components of learning planned, compiled, and used in the development of teaching materials.

\section{CONCLUSIONS}

\section{A. Test Results of Teaching Materials}

Based on the explanation above, this study can inform that basically the teaching material presented has teaching materials that are relevant to the lectures or English courses at the State University of Medan in Postgraduate School of study program. The relevance of this teaching material with the subject becomes the main characteristic and becomes the excellence of this research. Teaching materials based on language meta-functions are relevant to the field of Education Administration studies based on the Education Administration syllabus. All teaching materials which are provided in accordance with the field of study and development are aligned with the study program.

Teaching materials are designed to meet the special needs of students of the postgraduate students of Education Administration program. Teaching materials require more adequate methodology and activities for postgraduate students. Teaching materials encourage students to master grammar, vocabulary, registers, discourses, genres that are appropriate in accordance with activities.

\section{B. Validation Test Results of Teaching Materials}

Assessment of the feasibility of teaching materials; planning, implementing, and evaluating teaching materials which include suitability, clarity, accuracy, completeness of the learning model developed with several rules followed, for example: feasibility of learning planning, feasibility of learning implementation and feasibility of Learning Evaluation in formative and summative tests.

Thus, the language needs are found as the basis of the development model of teaching materials based on metafunctions and teaching materials that are in accordance with learning that encourages students to think critically in accordance with the competence of the academic field.

\section{ACKNOWLEDGMENTS}

Based on the conclusions, it is suggested that the instructional materials have been set and are ready to be presented. Teaching materials are taken from several aspects related to education and teaching, so that teaching materials can be implemented in increasing the quality of learning.

\section{REFERENCES}

[1] Brunton, M,An Account of ESP-W with Possible Future Directions. Journal English for Specific Purposes Issue.8 (4), 2009.

[2] Slavin, R.E, Synthesis of Research on Cooperative Learning. Educational Leadership, 48(5), 71-82, 1991.

[3] Gurning, B, Pengembangan Model Pembelajaran Menulis berbasis linguistic Fungsional Bagi Mahasiswa s1 Bahasa Inggris Unimed. Laporan Penelitian, FBS, Unimed, 2012.

[4] Gurning, B, Penggunaan Leksikogramatika dalam Teks Akademik: sebuah Kajian Berdasarkan Linguistik Fungsional Sistemik. Jurnal Penelitian Bidang Pendidikan Lembaga Penelitian Unimed, Terakreditasi, 12 (1), 1-8, 2005.

[5] Hutchitson, \&Waters, T, Engslish for Specifi Purposes. New York, Cambridge University Press, 1987.

[6] Halliday, M.A.K, An Introduction to Functional Grammar (Second Edition). London: Edward Arnold, 2004.

[7] Burns, A\&De Silva Joyce, H, Focus on grammar, Sydney, NCELTR, 1998.

[8] Gurning, B, Penggunaan Bahasa Inggris dalam Teks Ilmu-Ilmu Alam dan Teks Ilmu-Ilmu Sosial. Sebuah Analisis Berdasarkan Linguistik Fungsional. Laporan Penelitian. FBS, Unimed, 2006.

[9] Jordan, R.R,English for Academic Purposes: A Guide and Resources Book for Teachers. London: Cambridge University Press, 2007.

[10] Friedrichen, P.M, A Biologi Course for Prospective Elementary Teachers, Journal The American Biology Teacher, Vol. 63(8): 562$568,2001$.

[11] McMurarry, M.A. Beisenherz and Thompson, B.Reliability and Concurrent Validity of A Measure of Critical Thinking Skills in Biology. Journal of Research in Science Teacher, 28(2), 1991.

[12] Ordonez, V,Towards Lifelong Education for All. PARIS: InterParliamentary Conference on Education, Science, Culture, and Communication, 1996.

[13] Corebima, A.D, Pengukuran Kemampuan Berpikir pada Pembelajaran Sains. Seminar Nasional HEPI, Yogyakarta UNY, 14-15 Mei, 2005.

[14] Ustunluoglu, E, Language Teaching Through Critical Thinking and Self Awarness.Journal English Teaching Forum.42 (3), 2-7, 2004.

[15] Alexander, M.E., et al, Using the Four Questions Technique to Enhance Critical Thinking in Online Discussions. Merlot Journal of Online Leraning and Teaching, 6 (2), 410-413, 2010.

[16] Ardana, W, Reformasi Pembelajaran Menghadapi Abad Pengetahuan. Makalah disajikan dalam Seminar dan Diskusi Panel Teknologi Pembelajaran V. Malang: Program Studi TEP PPS UM, 2000.

[17] Borg, R,W, and Gall, M.D,Educational research an introduction. Fourth Edition. New york : Longman, 1983.

[18] Rothery, J, Making changes: developing an educational linguistics' in R. Hasan and G. Williams (eds.). Literacy in Society. London: Longman, 1996. 